\title{
Association between sexuality and quality of life in older adults
}

\author{
Associação entre sexualidade e qualidade de vida em idosos \\ Asociación entre sexualidad y calidad de vida de los adultos mayores
}

How to cite this article:

Souza Júnior EV, Cruz DP, Silva CS, Rosa RS, Santos GS, Sawada NO. Association between sexuality and quality of life in older adults. Rev Esc Enferm USP. 2021;55:e20210066. DOI: https://doi.org/10.1590/1980-220X-REEUSP-2021-0066

\section{Edison Vitório de Souza Júnior ${ }^{1}$ \\ Diego Pires Cruz ${ }^{2}$ \\ Cristiane dos Santos Silva ${ }^{3}$ \\ Randson Souza Rosa ${ }^{4}$ \\ (D) Gabriele da Silva Santos ${ }^{5}$ \\ (D) Namie Okino Sawada ${ }^{6}$}

${ }^{1}$ Universidade de São Paulo, Escola de Enfermagem de Ribeirão Preto, Programa de Pós-Graduacão em Enfermagem Fundamental, Ribeirão Preto, SP, Brazil.

${ }^{2}$ Universidade Estadual do Sudoeste da Bahia, Programa de Pós-Graduação em Enfermagem e Saúde, Jequié, BA, Brazil

${ }^{3}$ Universidade Norte do Paraná, Jequié, BA, Brazil.

${ }^{4}$ Universidade Federal de Minas Gerais, Faculdade de Medicina, Departamento de Medicina Preventiva e Social, Belo Horizonte, MG, Brazil.

${ }^{5}$ Universidade Federal da Bahia, Salvador, Bahia, Brazil.

${ }^{6}$ Universidade Federal de Alfenas, Programa de Pós-Graduação em Enfermagem, Alfenas, MG, Brazil.

\begin{abstract}
Objective: To analyze the association between the experiences of sexuality and quality of life in older adults. Method: Cross-sectional study developed with a total of 300 older adults living in northeastern Brazil. Data collection was carried out entirely online between August and October 2020. Participants completed the online questionnaire containing three instruments for assessing bio sociodemographic data, sexuality and quality of life. Data analysis was performed using the Mann-Whitney, Kruskal-Wallis, Spearman correlation and multivariate linear regression tests, adopting a 95\% confidence interval ( $<<0.05)$. Results: Older adults experience better affective relationships and have better quality of life in sensory abilities and intimacy. In the regression analysis, only affective relationships $(\beta=0.510$; [95\% CI: $0.340-0.682$; $\mathrm{p}<0.001)$ and physical and social adversities $(\beta=-0.180$; [95\% CI: $-1.443-0.434$; $\mathrm{p}<0.001)$ remained associated with the general quality of life of older adults. Conclusion: Health professionals must invest in training, development of individual and group educational interventions, in addition to promoting the strengthening of bonds between older adults so that they feel free and comfort in expressing their intimate needs.
\end{abstract}

\section{DESCRIPTORS}

Public Health; Health of the Elderly; Health Promotion; Family Health Strategy. 


\section{INTRODUCTION}

Population aging is a global phenomenon resulting from the achievement of some health indicators, especially the reduction in fertility and the increase in life expectancy ${ }^{(1)}$. In developed countries, people aged 65 years old and over are considered older adults. In developing countries, this classification encompasses individuals over 60 years old ${ }^{(2)}$.

It is estimated that by 2050 , the population aged 60 years old and over will reach 2.1 billion. For comparison, the number of older adults in 2015 was 1.4 billion worldwide. Thus, although advances in health have generated positive impacts on life expectancy, there is now a new focus: ensuring that the years of life are productive and healthy, configuring as a major challenge for research in aging area ${ }^{(3)}$.

In this scenario, as the aging process happens, the Quality of Life (QoL) of the older adults can be gradually reduced. QoL can be understood as a harmonious set of satisfactions considering the physical and psychosocial factors of life $\mathrm{f}^{(4)}$. It is an indicator of general well-being, involving positive and negative aspects of life, being a relevant measure to assess healthy and successful aging ${ }^{(3)}$, in addition to the individual's health status ${ }^{(2)}$.

The most common definition of QoL is proposed by the World Health Organization (WHO), which defines it as "the individual's perception of their position in life, in the context of the culture and value systems in which they live and in relation to their goals, expectations, standards and concerns"(5), which also includes the healthy experiences of sexuality.

Sexuality is a multifactorial construction that involves behaviors, functions, motivation, partnerships, attitudes, sexual intercourse ${ }^{(6-7)}$, intimacy, pleasure, eroticism, reproduction, beliefs, values, practices, fantasies, identity, desires, roles and relationships ${ }^{(8)}$. Therefore, it is understood that sexuality transcends the physical and sexual aspects and values various demonstrations of a more qualitative order.

It is informed that sexuality is as important in old age as in any other age group and its expression can be empowering, affirmative, happy and positive ${ }^{(8)}$. However, much of the research on sexuality in older adults is limited to addressing the physiological impacts of aging and the medical model of sexuality, almost always focused on the sexual response ${ }^{(6)}$, without considering the scope of sexuality in its concept, in satisfaction, on the well-being and QoL of older adults ${ }^{(8)}$.

Thus, the development of this study becomes relevant for two main reasons. The first concerns the scientific consolidation of sexuality in its broad concept, given the limitation of studies that deeply explore this breadth. Second, due to the growing aging of the population, it is necessary to reorient health practices to provide a better QoL for older adults, since the literature claims that this is a subject that is rarely addressed during health consultations for them ${ }^{(9-10)}$. Therefore, the aim of this study was to analyze the association between the experiences of sexuality and quality of life in older adults.

\section{METHOD}

\section{Type Of Study}

This is a cross-sectional study ${ }^{(11)}$ with a descriptive and analytical design, developed according to the checklist Strengthening the Reporting of Observational Studies in Epidemiology (STROBE).

\section{SetTing}

The study scenario was the Social Network Facebook platform, as data collection was completely online without face-to-face meetings between participants and researchers. Thus, the older adults participated from their homes with internet access.

\section{Sample Definition}

Participants were selected using the consecutive nonprobabilistic technique on the Facebook Social Network and met the following inclusion criteria: being 60 years old or older; being of both sexes (male or female); married, in a stable union or with a regular partner; living in northeastern Brazil; having internet access and an active Facebook account. All older adults living in long-term care institutions, hospitalized and dependent were excluded from the research. It is revealed that an instrument was not used to assess the cognitive ability of older adults, as it is understood that this ability is already preserved, as they actively participate in social networks and have the skills to handle equipment that gives access to the networks.

\section{Data Collection}

Data collect was carried out entirely online between August and October 2020. The creation of a Facebook page exclusively for the development of scientific research was used as a recruitment resource. On this page, the authors published a personalized invitation containing the names of the responsible researchers, institution of link, contact telephone, inclusion criteria and the hyperlink that directed participants to the online questionnaire built by the Google Forms tool.

In addition, the authors used the post boosting strategy, in which Facebook expanded the dissemination of the research to all older adults who met the inclusion criteria previously defined in the geolocation resource. The promotion is a service that, through payment, Facebook disseminates the publication to people with characteristics similar to what we defined when contracting the service and, with this, there is an increase in the possibility of the ad being liked, commented and also shared among the public, which facilitated the rapid dissemination of this research.

Before having access to the questionnaire, it was mandatory to include the e-mail in the requested field, so that it was possible to identify multiple responses by the same participant, reducing the chances of bias. The questionnaire was divided into four blocks: Informed Consent Form (ICF), bio sociodemographic, sexuality and QoL. 
The ICF block was the first page that participants had access to before answering the instruments. In this block, the researchers made the ICF available in its entirety, with an explanation of the objectives, justification, relevance, risks, benefits, in addition to the voluntary nature without harm or penalties for those involved. Thus, all research participants electronically read and accepted to participate in the study by selecting the option "I accept to participate in this study" available at the end of the ICF page. At the end of data collection, the researchers sent a duplicate of the consent form to all participants, through blind copy, to preserve personal data and avoid their identification by other people.

The bio sociodemographic block was built with questions that allowed to draw a profile of the participants such as education, religion, biological sex, ethnicity, age group, sexual orientation, among other information.

The sexuality block was constructed using the Affective and Sexual Experiences Scale for older adults (ASESOA) built and validated in Brazil ${ }^{(12)}$. ASESOA is structured in three dimensions: sexual act, affective relationships and physical and social adversities, which totals 38 questions with five possible answers: 1 = never, 2 = rarely, 3 = sometimes, $4=$ often and $5=$ always. The results are interpreted considering that the lowest/highest score corresponds, respectively, to the worst/better experience of sexuality in old age. The internal consistency obtained through Cronbach's Alpha revealed acceptable values for all dimensions: sexual intercourse $(\alpha=0.96)$, affective relationships $(\alpha=0.96)$, and physical and social adversities $(\alpha=0.71)^{(12)}$.

The QoL block was built with the World Health Organization Quality of Life - Old (WHOQOL-Old) ${ }^{(13)}$. This is a specific instrument for the older adult population and contains 24 questions distributed into six facets: sensory skills; autonomy; past, present and future activities; social participation; death and dying and intimacy. There are five possible answers arranged on a Likert scale from 1 to 5 points. The final score ranges from 24 to 100 points and the highest/lowest score indicates, respectively, better/ worse QoL ${ }^{(13-14)}$. Cronbach's alpha values were adequate for all facets of assessment, ranging from 0.70 (autonomy facet) to 0.885 (general scale), demonstrating good psychometric performance for assessing QoL in older adults ${ }^{(13)}$.

\section{Data Analysis}

For data analysis, non-parametric statistics were used after verifying the abnormality of the data using the Kolmogorov-Smirnov test $(p<0.05)^{(15)}$. To compare the bio sociodemographic variables with sexuality and QoL, the Mann-Whitney U test was used for variables with two categories and the Kruskal-Wallis test for variables with more than two categories with application of post-hoc Bonferroni when necessary ${ }^{(15)}$. In order to understand how the independent variable (sexuality) and the outcome (QoL) were related, a Spearman correlation analysis $(\rho)$ was performed, with subsequent multivariate linear regression ${ }^{(15)}$ for the variables that presented $\mathrm{p}$-value $<0.05$.

Regression results were expressed by Beta $(\beta)$ coefficients (standardized and non-standardized); confidence intervals; $\mathrm{p}$ value and coefficient of determination $\left(\mathrm{R}^{2}\right)$. The adequacy of the model was verified by the Durbin Watson test, and an adequate model is the one that presents values closer to $2^{(15)}$. Quantitative variables were presented through mean ranks, medians and interquartile range (IQ), and qualitative variables through absolute and relative frequencies. It is noteworthy that a confidence interval of $95 \%(\mathrm{p}<0.05)$ was adopted for all statistical analyses.

\section{Ethical Aspects}

It is noteworthy that this study strictly complied with all ethical requirements for the development of research with human beings, according to Resolution 466/2012 of the National Health Council. In addition, this study was approved by the Research Ethics Committee of the Nursing School of Ribeirao Preto, University of Sao Paulo, under Opinion No. 4319644 in 2020.

\section{RESULTS}

Most participants were men (68.7\%), aged between 60 and 64 years old (42.7\%), self-declared white (71.0\%), who do not live with their children (67.7\%) and who never received guidance on sexuality by health professionals (75.7\%). The other bio sociodemographic characteristics are shown in Table 1.

With regard to sexuality, it is observed in Table 2, that older adults experience the best in affective relationships, as evidenced by the highest median in the respective dimension. However, there is a better perception of QoL in the facets of social skills and intimacy, both with the same median.

It is observed in Table 3 that women have a better perception of QoL in the "sensory skills" domain (165.97; $\mathrm{p}=0.035)$. In addition, older adults between 65- and 69years old experience the sexual intercourse better (156.35; $\mathrm{p}=0.039)$.

Participants who have a regular partner experience the sexual intercourse better (198.27; $\mathrm{p}<0.001)$; affective relationships (176.91; $\mathrm{p}=0.004)$ and better face physical and social adversities $(120.16 ; \mathrm{p}=0.027)$ when compared to married older adults. Nevertheless, older adults in a stable relationship have better QoL in the facets of sensory abilities $(185.60 ; p=0.015)$ and autonomy (179.26; $\mathrm{p}=0.046)$ when compared to married ones.

Finally, it is noted that older adults who live with their partners for less than or equal to 5 years experience the sexual intercourse better (184.09; p < 0.001) compared to older adults who live for more than 20 years (131.96; $\mathrm{p}<0.001)$. The other findings are described in Table 3.

Table 4 shows that there was a statistically significant correlation in all dimensions of sexuality with QoL, except for the sexual intercourse $(\rho=0.069 ; p=0.235)$ and affective relationships $(\rho=0.074 ; p=0.200)$, which were not correlated with sensory abilities. It is also noteworthy that the sexual act and affective relationships have positive correlations with QoL, while physical and social adversities have negative correlations. The highest correlation identified 
Table 1 - Bio sociodemographic variables of the participants Ribeirao Preto, SP, Brazil, 2020.

\begin{tabular}{|c|c|c|}
\hline Variables & $\mathbf{n}$ & $\%$ \\
\hline \multicolumn{3}{|l|}{ Gender } \\
\hline Male & 206 & 68.7 \\
\hline Female & 94 & 31.3 \\
\hline \multicolumn{3}{|l|}{ Age } \\
\hline Between 60 and 64 & 128 & 42.7 \\
\hline Between 65 and 69 & 105 & 35.0 \\
\hline Between 70 and 74 & 49 & 16.3 \\
\hline Between 75 and 79 & 15 & 5.0 \\
\hline Between 80 and 84 & 3 & 1.0 \\
\hline \multicolumn{3}{|l|}{ Religion } \\
\hline Catholic & 187 & 62.3 \\
\hline Protestant & 37 & 12.3 \\
\hline Spiritualist & 27 & 9.0 \\
\hline Religions of African origins & 5 & 1.7 \\
\hline Others & 13 & 4.3 \\
\hline No religion & 31 & 10.3 \\
\hline \multicolumn{3}{|l|}{ Education } \\
\hline Primary & 30 & 10.0 \\
\hline Elementary I & 18 & 6.0 \\
\hline Elementary II & 19 & 6.3 \\
\hline High school & 95 & 31.7 \\
\hline Higher education & 137 & 45.7 \\
\hline No education & 1 & 0.3 \\
\hline \multicolumn{3}{|l|}{ Marital status } \\
\hline Married & 210 & 70.0 \\
\hline Stable union & 42 & 14.0 \\
\hline With a regular partner & 48 & 16.0 \\
\hline \multicolumn{3}{|l|}{ Time spent with the partner } \\
\hline$\leq 5$ years & 43 & 14.3 \\
\hline Between 6 and 10 years & 22 & 7.3 \\
\hline Between 11 and 15 years & 18 & 6.0 \\
\hline Between 16 and 20 years & 16 & 5.3 \\
\hline$>20$ years & 201 & 67.0 \\
\hline \multicolumn{3}{|l|}{ Sexual orientation } \\
\hline Heterosexual & 264 & 88.0 \\
\hline Homosexual & 5 & 1.7 \\
\hline Bisexual & 4 & 1.3 \\
\hline Others & 27 & 9.0 \\
\hline
\end{tabular}

was strong and positive between affective relationships and intimacy $(\rho=0.558 ; p<0.001)$.

In the linear regression analysis, it was observed that only the components "affective relationships" and "physical and social adversities" remained associated with different facets of QoL. All associations identified with affective relationships were positive and, with physical and social adversities, negative, as shown in Table 5. In addition, it is observed that
Table 2 - Evaluation of sexuality and QoL of participants Ribeirao Preto, SP, Brazil, 2020.

\begin{tabular}{lc}
\hline Variables & Median (IQ) \\
\hline Sexuality & $74.00(63.00-80.00)$ \\
Sexual intercourse & $75.00(67.00-81.00)$ \\
Affective relationships & $7.00(5.00-9.00)$ \\
Physical and social adversity & \\
\hline QoL & $75.00(68.75-93.75)$ \\
Sensory skills & $68.75(56,25-75.00)$ \\
Autonomy & $68.75(56.25-75.00)$ \\
Past, present and future activities & $68.75(56.25-75.00)$ \\
Social participation & $68.75(56.25-75.00)$ \\
Death and dying & $75.00(68.75-81.25)$ \\
Intimacy & $68.75(60.41-78.12)$ \\
General QoL &
\end{tabular}

the greater magnitude of the influence of factors (sexuality) on attributes (facets of QOL) was identified between affective relationships and intimacy $[\beta=0.678 ;(95 \% \mathrm{CI}=$ $0.705-1.107 ; \mathrm{p}<0.001)$, and the model explained $50.7 \%$ of the data variation.

\section{DISCUSSION}

It was observed in this study that older adults experience their sexuality better in affective relationships. This dimension refers to the qualitative aspects of sexuality such as companionship, love, complicity, affection, friendship, support, partnership, among others ${ }^{(12)}$.

These results are in agreement with other studies ${ }^{(16-17)}$, in which they identified the different ways that older adults express their sexuality, among which altruism, affection, attention, attractiveness and respect prevailed. In a qualitative study ${ }^{(17)}$, for example, the sexual intercourse was not readily evoked as a central element of social representation, but as an intermediary element, making room for other expressions of feeling and affection.

For older adults, sexuality is seen from a new perspective, in which sexual desire can be replaced by emotional expressions of care and affection for the spouse and sexual activity takes a secondary position in the relationship ${ }^{(18)}$.

With regard to QoL, it was noted that older adults have better scores in sensory skills and intimacy facets, corroborating other similar studies ${ }^{(19-20)}$. Thus, it was observed that women have a better perception of $\mathrm{QoL}$ in the sensory skills domain. These skills involve the impact of the loss of senses (hearing, sight, taste, smell and touch) on the older adults' capacity for social interaction and daily life activities. Intimacy, on the other hand, assesses their ability to have intimate and personal relationships ${ }^{(14)}$.

Older adults aged between 65 and 69 years old experience the sexual intercourse better $(156.35 ; \mathrm{p}=0.039)$, weakening the prejudices, myths and taboos existing in society that attribute to older adults a position of asexuality ${ }^{(21)}$.

It is noteworthy that older adults remain active in their sexual experiences, including individual masturbation 
Table 3 - Comparison of bio sociodemographic variables with sexuality and QoL - Ribeirao Preto, SP, Brazil, 2020.

\begin{tabular}{|c|c|c|c|c|c|c|c|c|c|c|}
\hline & \multicolumn{3}{|c|}{ Sexuality } & \multicolumn{7}{|c|}{ QoL } \\
\hline & SI & AR & PSA & SS & AUT & PPFA & SP & DD & INT & GQL \\
\hline \multicolumn{11}{|c|}{ Health centers } \\
\hline \multicolumn{11}{|l|}{ Gender } \\
\hline Male & 145.61 & 145.41 & 153.47 & 143.44 & 150.27 & 150.23 & 151.18 & 155.17 & 148.31 & 149.29 \\
\hline Female & 161.22 & 161.66 & 143.99 & 165.97 & 151.01 & 151.09 & 149.02 & 140.26 & 155.29 & 153.15 \\
\hline $\mathrm{p}$ value & 0.148 & 0.132 & 0.376 & 0.035* & 0.945 & 0.936 & 0.839 & 0.165 & 0.507 & 0.721 \\
\hline \multicolumn{11}{|l|}{ Age range } \\
\hline 60-64 years old & 155.21 & 152.28 & 142.63 & 145.31 & 157.46 & 153.37 & 149.16 & 148.08 & 152.39 & 150.98 \\
\hline 65-69 years old & 156.35 & 155.32 & 151.59 & 146.51 & 155.15 & 148.23 & 150.85 & 160.18 & 156.77 & 156.09 \\
\hline $70-74$ years old & 145.83 & 141.08 & 163.42 & 170.48 & 134.68 & 153.01 & 160.31 & 138.62 & 146.42 & 146.88 \\
\hline $75-79$ years old & 108.17 & 144.73 & 145.90 & 162.97 & 124.40 & 147.40 & 151.03 & 134.00 & 120.07 & 139.10 \\
\hline 80-84 years old & 32.83 & 88.50 & 260.50 & 122.67 & 79.67 & 82.00 & 32.67 & 191.50 & 69.00 & 50.50 \\
\hline$p$ value & $0.039^{\dagger}$ & 0.634 & 0.129 & 0.411 & 0.184 & 0.703 & 0.174 & 0.468 & 0.239 & 0.311 \\
\hline \multicolumn{11}{|l|}{ Marital status } \\
\hline Married & $134.46^{\ddagger}$ & $139.66^{\ddagger}$ & $155.41^{\ddagger}$ & $143.35^{\ddagger}$ & $143.66^{\ddagger}$ & 151.73 & 150.02 & 151.77 & 146.49 & 147.19 \\
\hline Stable union & 176.10 & 174.50 & 160.61 & $185.60^{\ddagger}$ & $179.26^{\ddagger}$ & 149.42 & 155.07 & 155.67 & 164.21 & 165.67 \\
\hline Regular partner & $198.27^{\ddagger}$ & $176.91^{\ddagger}$ & $120.16^{\ddagger}$ & 151.09 & 155.24 & 146.06 & 148.58 & 140.41 & 156.05 & 151.71 \\
\hline$p$ value & $<0.001^{+}$ & $0.004^{\dagger}$ & $0.027^{\dagger}$ & $\mathbf{0 . 0 1 5}^{+}$ & $\mathbf{0 . 0 4 6}^{+}$ & 0.915 & 0.918 & 0.654 & 0.408 & 0.449 \\
\hline \multicolumn{11}{|c|}{ Time living together } \\
\hline$\leq 5$ years & $184.09^{\ddagger}$ & 165.65 & 136.27 & 152.43 & 166.05 & 161.87 & 149.74 & 148.13 & 163.02 & 159.55 \\
\hline 6-10 years & 204.34 & 186.16 & 126.07 & 169.75 & 166.36 & 160.2 & 165.64 & 160.32 & 173.93 & 169.27 \\
\hline 11-15 years & 174.78 & 161.78 & 178.03 & 155.19 & 175.47 & 141.53 & 172.28 & 158.00 & 175.25 & 172.11 \\
\hline 16-20 years & 191.84 & 173.44 & 142.06 & 163.88 & 197.16 & 158.59 & 153.03 & 184.69 & 157.97 & 185.91 \\
\hline$>20$ years & $131.96^{\ddagger}$ & 140.52 & 154.43 & 146.50 & 139.49 & 147.16 & 146.85 & 146.54 & 142.45 & 141.76 \\
\hline$p$ value & $<0.001^{+}$ & 0.058 & 0.252 & 0.736 & $0.020^{+}$ & 0.796 & 0.693 & 0.497 & 0.189 & 0.119 \\
\hline
\end{tabular}

*Statistical significance by Mann-Whitney test $(p<0.05)$.

${ }^{+}$Statistical significance by the Kruskal-Wallis test $(p<0.05)$.

${ }^{\ddagger}$ Differences between groups by Bonferroni post-hoc.

SI: sexual intercourse; AR: affective relationships; PSA: physical and social adversity; SS: sensory skills; AUT: autonomy; PPFA: past, present and future activities; SP: social participation; DD: death and dying; INT: intimacy; GQL: general quality of life.

practices $^{(6-7)}$. Thus, a study carried out with 213 Portuguese older adults is cited that corroborates this evidence, in which it was found that most participants had sexual relations at least once weekly or monthly ${ }^{(22)}$.

As much as there is a reduction in the frequency of sexual intercourse among older adults ${ }^{(7)}$, it does not mean the finitude of its expression. In old age, there is a transformation of sexual energy that transcends the quantitative aspect and begins to be expressed in a more qualitative way ${ }^{(18)}$. Therefore, it should be remembered that aging is not synonymous with asexuality, but constitutes a stage of life in which sexuality is adapted to the specifics of the period of life $\mathrm{e}^{(18)}$.

Regularity in sexual activities contributes to physical and psychological well-being, in addition to reducing physical and mental health problems related to the aging process. Thus, it is mentioned, for example, that the involvement in sexual activities is correlated with lower rates of depressive symptoms; greater quality in relationships; increased self-esteem; better cardiovascular health in both sexes $^{(23)}$, in addition to reaffirming the identity of those involved, emphasizing their values and stimulating feelings of affection, warmth, love and affection ${ }^{(18)}$.

In this context, the Ministry of Health of Brazil reinforces the relevance of considering the sexual aspects of older adults, not only for the prevention of Sexually Transmitted Infections, but by recognizing that the sexual intercourse is a structuring component, including the QoL in this population ${ }^{(9)}$. However, in this study, the regression analysis did not identify an association between the sexual intercourse and the facets of QoL, but affective relationships gained prominence with positive and statistically significant associations, revealing that the more intense the experiences of these relationships, the better will be the QoL of the older adults investigated.

With regard to marital status, older adults who have a regular partner experience the sexual intercourse better, affective relationships and better face physical and social adversities compared to married older adults. The dimension of sexuality entitled "physical and social adversity" concerns three components: health problems that interfere with sexual activities; the fear of suffering prejudice due to the attitudes 
Table 4 - Correlation between sexuality and QoL of older adults Ribeirao Preto, SP, Brazil, 2020.

\begin{tabular}{|c|c|c|c|}
\hline $\begin{array}{c}\text { Dimensions of } \\
\text { ASESOA }\end{array}$ & Facets of QoL & $\begin{array}{c}\text { Spearman's } \\
\rho\end{array}$ & $p$ value \\
\hline \multirow{7}{*}{$\begin{array}{l}\text { Sexual } \\
\text { intercourse }\end{array}$} & Sensory skills & $0.069^{+}$ & 0.235 \\
\hline & Autonomy & $0.392^{+}$ & $<0.001 *$ \\
\hline & $\begin{array}{l}\text { Past, present and future } \\
\text { activities }\end{array}$ & $0.395^{+}$ & $<0.001 *$ \\
\hline & Social participation & $0.396^{+}$ & $<0.001^{*}$ \\
\hline & Death and dying & $0.195^{\dagger}$ & $0.01 *$ \\
\hline & Intimacy & $0.520^{\S}$ & $<0.001^{*}$ \\
\hline & General quality of life & $0.497^{\ddagger}$ & $<0.001 *$ \\
\hline \multirow{8}{*}{$\begin{array}{l}\text { Affective } \\
\text { relationships }\end{array}$} & Sensory skills & $0.074^{+}$ & 0.200 \\
\hline & Autonomy & $0.372^{+}$ & $<0.001 *$ \\
\hline & $\begin{array}{l}\text { Past, present and future } \\
\text { activities }\end{array}$ & $0.390^{+}$ & $<0.001 *$ \\
\hline & Social participation & $0.353^{+}$ & $<0.001^{*}$ \\
\hline & Death and dying & $0.227^{+}$ & $<0.001 *$ \\
\hline & Intimacy & $0.558^{\S}$ & $<0.001 *$ \\
\hline & General quality of life & $0.490^{\ddagger}$ & $<0.001 *$ \\
\hline & Sensory skills & $-0.267^{+}$ & $<0.001 *$ \\
\hline \multirow{6}{*}{$\begin{array}{l}\text { Physical and } \\
\text { social adversity }\end{array}$} & Autonomy & $-0.218^{\dagger}$ & $<0.001 *$ \\
\hline & $\begin{array}{l}\text { Past, present and future } \\
\text { activities }\end{array}$ & $-0.248^{+}$ & $<0.001 *$ \\
\hline & Social participation & $-0.235^{+}$ & $<0.001 *$ \\
\hline & Death and dying & $-0.159^{+}$ & $<0.001 *$ \\
\hline & Intimacy & $-0.265^{+}$ & $<0.001 *$ \\
\hline & General quality of life & $-0.340^{+}$ & $<0.001^{*}$ \\
\hline
\end{tabular}

*Statistical significance by Spearman's $\rho(p<0,05)$.

+Weak correlation.

${ }^{\ddagger}$ Moderate correlation.

§Strong correlation. taken to experience sexuality and the feeling of discomfort due to changes in sexuality resulting from aging ${ }^{(12)}$.

The literature shows that marital status can influence the importance that older adults attach to their sexual life, as well as to the satisfaction and maintenance of a sexually active life ${ }^{(22)}$. In this perspective, it was expected that the best experiences of sexuality, including its three dimensions of the ASESOA instrument, would be found among married older adults, as in marriage, spouses have greater freedom from a social and religious point of view to explore different sexual approaches as a way of to strengthen the bonds of marriage ${ }^{(24)}$.

However, it is inferred that the monotony that appears after a few years of marriage ${ }^{(25)}$ is one of the reasons why married older adults in this study experience their sexuality worse. It should also be remembered that, in general, older adults start their relationships from youth and live with their spouses until old age ${ }^{(26)}$, which can facilitate the installation of routine and marital monotony.

This evidence may even explain why older adults who live with their partners for less than or equal to 5 years experience the sexual act better than those who live with their partners for more than 20 years; and why older adults in a stable relationship have better QoL in the facets of sensory abilities and autonomy compared to married ones. In fact, the results found in this study point to marriage as a possible factor that condition older adults to a possible self-indulgence in their relationships.

Another relevant finding of this study was the statistically significant and negative associations between physical and social adversities, indicating an inversely proportional behavior and, as such adversities increase, there is a reduction in QoL. In fact, the literature confirms that sexuality is directly

Table 5 - Final linear regression models for sexuality components and QoL facets - Ribeirao Preto, SP, Brazil, 2020.

\begin{tabular}{|c|c|c|c|c|c|c|}
\hline & $\beta$ & Standardized $\beta$ & Cl 95\% & p & Durbin-Watson & $\mathbf{R}^{2}$ \\
\hline \multicolumn{7}{|c|}{ Sensory skills } \\
\hline Physical and social adversity & -1.689 & -0.251 & $-2.482--0.896$ & $<0.001$ & 2.008 & 0.057 \\
\hline \multicolumn{7}{|c|}{ Autonomy } \\
\hline Affective relationships & 0.501 & 0.335 & $0.218-0.784$ & 0.001 & \multirow{2}{*}{1.824} & \multirow{2}{*}{0.221} \\
\hline Physical and social adversity & -0.849 & -0.109 & $-1.685--0.014$ & 0.046 & & \\
\hline \multicolumn{7}{|c|}{ Past, present and future activities } \\
\hline Affective relationships & 0.645 & 0.453 & $0.384-0.906$ & $<0.001$ & \multirow{2}{*}{2.034} & \multirow{2}{*}{0.266} \\
\hline Physical and social adversity & -0.807 & -0.109 & $-1.578--0.037$ & 0.040 & & \\
\hline \multicolumn{7}{|c|}{ Social participation } \\
\hline Affective relationships & 0.364 & 0.243 & $0.078-0.650$ & 0.013 & 1.932 & 0.202 \\
\hline \multicolumn{7}{|c|}{ Death and dying } \\
\hline Affective relationships & 0.647 & 0.328 & $0.241-1.052$ & 0.002 & 1.801 & 0.074 \\
\hline \multicolumn{7}{|c|}{ Intimacy } \\
\hline Affective relationships & 0.906 & 0.678 & $0.705-1.107$ & $<0.001$ & 2.086 & 0.507 \\
\hline \multicolumn{7}{|c|}{ General quality of life } \\
\hline Affective relationships & 0.511 & 0.510 & $0.340-0.682$ & $<0.001$ & \multirow{2}{*}{1.869} & \multirow{2}{*}{0.365} \\
\hline Physical and social adversity & -0.938 & -0.180 & $-1.443--0.434$ & $<0.001$ & & \\
\hline
\end{tabular}


related to QoL ${ }^{(27-28)}$ with relevant implications over the years, contributing to self-knowledge, well-being, pleasure, self-esteem ${ }^{(16)}$, health maintenance. mental and general satisfaction with life ${ }^{(29)}$.

It should be remembered that sexuality remains in old age in a different way, depending on the specificities of each individual, and both the QoL and the satisfaction with life depend on the affective and sexual experiences of older adults ${ }^{(18)}$, and they consider sexuality an important part of life ${ }^{(6)}$.

However, despite sexuality being recognized for its benefits to the health and QoL of this population, obstacles in the professional-patient relationship are found in the literature when the subject is sexuality in this age group.

As an example, a study ${ }^{(10)}$ carried out with a total of 155 medical professionals is cited, which revealed that $63.9 \%$ of these professionals do not address sexuality in consultations with older adults, and the main reasons for this situation were the lack of time, fear of embarrassment and technical incapacity for the approach ${ }^{(10)}$. Another study ${ }^{(1)}$ carried out with 50 women revealed that participants are afraid to talk about sexuality, especially with health professionals.

Another study ${ }^{(27)}$ developed with 100 women identified that only $25 \%$ of the participants had already reported some type of dialogue with a health professional about sexuality. Finally, another study ${ }^{(30)}$ developed with 126 older adults showed that $73.81 \%$ reported difficulty in starting a dialogue about aspects related to the sexual intercourse.

Still in this follow-up, the literature reveals that nursing care for older adults in the FHS is limited to drug actions, immunization and identification of risk situations and/or violence, with no individualized consultation that meets the sexuality needs of older adults ${ }^{(9)}$. Somehow, this evidence corroborates the results of this study, in which $75.7 \%$ of older adults never received guidance on sexuality by health professionals.

In this perspective, the indispensability of health professionals to receive training on sexuality is revealed, in such a way that they understand its broad dimension, as well as the multifactorial aspects that involve it. This is a need considered a priority in relation to the theme for professionals to acquire skills in including sexuality in care plans for older adults as a way of promoting and protecting QoL.

After acquiring the necessary knowledge and skills, it is necessary for health professionals to develop educational actions as a strategy to deconstruct socially constructed judgments and prejudices about the sexuality of older adults $^{(1)}$. These professionals, especially those who work in the Family Health Strategy (FHS) have a relevant role in promoting the health of older adults and one of the factors that contribute to strengthening this objective is the longitudinally of care, capable of strengthening the relationships between professional users with mutual trust, culminating in freedom and comfort for older adults to express their intimate needs, especially those related to sexuality ${ }^{(9)}$.

Thus, it is revealed that the welcoming care offered by health professionals to older adults can empower them to break social barriers and fully enjoy their sexuality. This care should be based, especially, on freedom from prejudice and through information aimed at valuing doubts, self-esteem and insecurities, thus contributing to the biopsychosocial well-being of older adults ${ }^{(9)}$.

It is noteworthy that this study has some limitations. First, the non-probabilistic sampling technique adopted in the methodological design does not allow the generalization of results. Second, as this is a study whose data collection took place exclusively online, the participation of older adults may have been restricted to individuals with higher socioeconomic status, which can be proven by their high prevalence with higher education identified in this study, a distant reality of older adults in the Northeast, especially users of the Unified Health System, despite its universal character.

However, these limitations do not invalidate our findings, as they can contribute to the expansion of the holistic view of health professionals towards the sexuality of older adults, regardless of socioeconomic level. After all, sexuality is a structuring component of human identity that must be experienced by everyone, if they so wish. Therefore, it is suggested that more studies be developed with older adults from different social strata, to scientifically solidify the impact of sexuality on the living and health conditions of this population that needs new interventions that add better quality to additional years of life.

\section{CONCLUSION}

This study allowed us to conclude that older adults better experience their sexuality through affective relationships. In addition, sexuality is a component that was associated with the QoL of the investigated people. It was also observed that only the components "affective relationships" and "physical and social adversities" remained associated with different facets of QoL. All associations identified with affective relationships were positive and, with physical and social adversities, negative. This means that, the greater the experiences of affective relationships, the better the QoL. On the other hand, the greater the confrontation with physical and social adversities related to sexuality, the worse the older adults' QoL will be.

Therefore, our results can influence the decision-making of all health professionals, especially in primary care, to seek above all training on the subject so that, based on acquired skills, they are able to develop individual and group educational strategies with older adults about sexuality, strengthening bonds and encouraging freedom, autonomy and freedom from prejudice.

\section{RESUMO}

Objetivo: Analisar a associação entre as vivências da sexualidade e a qualidade de vida nos idosos. Método: estudo transversal desenvolvido com 300 idosos residentes no Nordeste do Brasil. A coleta de dados foi realizada totalmente online entre os meses de agosto e outubro de 2020. Os participantes preencheram o questionário online contendo três instrumentos para avaliação dos dados 
biossociodemográficos, sexualidade e qualidade de vida. Realizou-se a análise dos dados com o teste de Mann-Whitney, Kruskal-Wallis, correlação de Spearman e regressão linear multivariada, adotando intervalo de confiança de 95\% (p < 0,05). Resultados: os idosos melhor experienciam as relações afetivas e possuem melhor qualidade de vida nas habilidades sensoriais e intimidade. Na análise de regressão, somente as relações afetivas ( $\beta=0,510$; [IC 95\%: 0,340-0,682]; $p<0,001)$ e as adversidades física e social $(\beta=-0,180$; [IC 95\%:-1,443 $--0,434] ; \mathrm{p}<0,001)$ permaneceram associadas à qualidade de vida geral dos idosos. Conclusão: os profissionais de saúde devem investir em capacitações, desenvolvimento de intervenções educativas individuais e grupais, além de promover o fortalecimento de vínculo entre os idosos para que estes sintam liberdade e conforto em expressar suas necessidades íntimas.

\section{DESCRITORES}

Saúde Pública; Saúde do Idoso; Promoção da Saúde; Estratégia Saúde da Família.

\section{RESUMEN}

Objetivo: Analizar la asociación entre las vivencias de la sexualidad y la calidad de vida de adultos mayores. Método: Se trata de un estudio transversal desarrollado entre 300 adultos mayores residentes en el Nordeste de Brasil. La recogida de los datos se 1 levó a cabo totalmente en línea entre los meses de agosto y octubre de 2020. Los participantes completaron el cuestionario en línea que contenía tres instrumentos para evaluar los datos biosociodemográficos, la sexualidad y la calidad de vida. El análisis de los datos se realizó mediante la prueba de Mann-Whitney, la prueba de Kruskal-Wallis, la correlación de Spearman y la regresión lineal multivariada, adoptando un intervalo de confianza del 95\% ( $<$ < 0,05) Resultados: Los adultos mayores experimentan mejor las relaciones afectivas y tienen mejor calidad de vida en las habilidades sensoriales y en la intimidad. En el análisis de regresión, sólo las relaciones afectivas $(\beta=0,510$; [IC 95\%: 0,340-0,682]; $p$ <,001) y la adversidad física y social $(\beta=-0,180$; [IC 95\%: $-1,443-0,434$; $p<0,001)$ se mantuvieron asociadas a la calidad de vida global de los mayores. Conclusión: Los profesionales de la salud deben invertir en capacitación, en desarrollo de intervenciones educativas individuales y grupales, además de promover el fortalecimiento del vínculo entre los mayores para que se sientan libres y cómodos para expresar sus necesidades más íntimas.

\section{DESCRIPTORES}

Salud Pública; Salud del Anciano; Promoción de la Salud; Estrategia de Salud Familiar.

\section{REFERENCES}

1. Souza CL, Gomes VS, Silva RL, Silva ES, Alves JP, Santos NR, et al. Aging, sexuality and nursing care: the elderly woman's look. Rev Bras Enferm. 2019;72(supl 2):78-85. DOI: https://doi.org/10.1590/0034-7167-2018-0015

2. Vagetti GC, Barbosa Filho VC, Moreira NB, Oliveira V, Mazzardo O, Campos W. Association between physical activity and quality of life in the elderly: A systematic review, 2000-2012. Rev Bras Psiquiatr. 2014;36(1):76-88. DOI: https://doi.org/10.1590/1516-4446-2012-0895

3. Govindaraju T, Sahle BW, McCaffrey TA, McNeil JJ, Owen AJ. Dietary patterns and quality of life in older adults: A systematic review. Nutrients. 2018;10(8):971. DOI: https://doi.org/10.3390/nu10080971

4. Oliveira LDSSCB, Souza EC, Rodrigues RAS, Fett CA, Piva AB. The effects of physical activity on anxiety, depression, and quality of life in elderly people living in the community. Trends Psychiatry Psychother. 2019;41(1):36-42. DOI: http://dx.doi.org/10.1590/2237-60892017-0129

5. The Whoqol Group. The World Health Organization Quality of Life Assessment (WHOQOL): development and general psychometric properties. Soc Sci Med. 1998;46(12):1569-85. DOI: http://dx.doi.org/10.1016/s0277-9536(98)00009-4

6. Srinivasan S, Glover J, Tampi RR, Tampi DJ, Sewell DD. Sexuality and the Older Adult. Curr Psychiatry Rep. 2019;21:97. DOI: https:// doi.org/10.1007/s11920-019-1090-4

7. Lindau ST, Schumm LP, Laumann EO, Levinson W, O'Muircheartaigh CA, Waite LJ. A Study of Sexuality and Health among Older Adults in the United States. N Engl J Med. 2007;357(8):762-74. DOI: https://doi.org/10.1056/NEJMoa067423

8. Heath H. Sexuality and sexual intimacy in later life. Nurs Older People. 2019;31(1):40-8. DOI: https://doi.org/10.7748/nop.2019.e1102

9. Evangelista AR, Moreira ACA, Freitas CASL, Val DR, Diniz JL, Azevedo SGV. Sexuality in old age: Knowledge/attitude of nurses of family health strategy. Rev Esc Enferm USP. 2019;53:e03482. DOI: http://dx.doi.org/10.1590/s1980-220x2018018103482

10. Cherpak GL, Santos FC. Assessment of physicians' addressing sexuality in elderly patients with chronic pain. Einstein (Sao Paulo). 2016;14(2):178-84. DOI: https://doi.org/10.1590/S1679-45082016AO3556

11. Newman TB, Browner WS, Cummings SR, Hulley SB. Designing an observational study: cross-sectional and case-control studies. In: Hulley SB, Cummings SR, Browner WS, Grady D, Newman TB, editors. Designing clinical research. 3rd ed. Porto Alegre: Artmed; 2008.

12. Vieira KFL. Sexualidade e qualidade de vida do idoso: desafios contemporâneos e repercussões psicossociais [Thesis]. João Pessoa: Universidade Federal da Paraíba; 2012.

13. Fleck MP, Chachamovich E, Trentini C. Development and validation of the Portuguese version of the WHOQOL-OLD module. Rev Saúde Pública. 2006;40(5):785-91. DOI: https://doi.org/10.1590/S0034-89102006000600007

14. Scherrer Júnior G, Okuno MFP, Oliveira LM, Barbosa DA, Alonso AC, Fram DS, et al. Quality of life of institutionalized aged with and without symptoms of depression. Rev Bras Enferm. 2019;72(2):127-33. DOI: https://doi.org/10.1590/0034-7167-2018-0316

15. Field A. Descobrindo a estatística usando o SPSS. 2nd ed. Porto Alegre: Artmed; 2009.

16. Humboldt S, Ribeiro-Gonçalves J, Costa A, Leal I. How do older adults express themselves sexually? An exploratory study. Psicol Saúde Doença. 2020;21(1):62-8. DOI: http://dx.doi.org/10.15309/20psd210110

17. Queiroz MAC, Lourenço RME, Coelho MMF, Miranda KCL, Barbosa RGB, Bezerra STF. Social representations of sexuality for the elderly. Rev Bras Enferm. 2015;68(4):662-7. DOI: http://dx.doi.org/10.1590/0034-7167.2015680413i

18. Barros TAF, Assunção ALA, Kabengele DC. Sexualidade na terceira idade: sentimentos vivenciados e aspectos influenciadores. Ciências Biológicas e Saúde Unit [Internet]. 2020 [cited 2020 Oct 28];6(1):47-62. Available from: https://periodicos.set.edu.br/fitsbiosaude/article/ view/6560 
19. Almeida BL, Souza MEBF, Rocha FC, Fernandes TF, Evangelista CB, Ribeiro KSMA. Quality of life of elderly people who practice physical activities. Rev Fun Care Online. 2020;12:432-6. DOI: https://doi.org/10.9789/2175-5361.rpcfo.v12.8451

20. Manso MEG, Maresti LTP, Oliveira HSB. Analysis of quality of life and associated factors in a group of elderly persons with supplemental health plans in the city of São Paulo, Brazil. Rev Bras Geriatr Gerontol. 2019;22(4):e190013. DOI: http://dx.doi.org/10.1590/198122562019022.190013

21. Uchôa YS, Costa DCA, Silva Junior IAP, Silva STSE, Freitas WMTM, Soares SCS. Sexuality through the eyes of the elderly. Rev Bras Geriatr Gerontol. 2016;19(6):939-49. DOI: http://dx.doi.org/10.1590/1981-22562016019.150189

22. Cambão M, Sousa L, Santos M, Mimoso S, Correia S, Sobral D. QualiSex: estudo da associação entre a qualidade de vida e a sexualidade nos idosos numa população do Porto. Rev Port Med Geral Fam. 2019;35(1):12-20. DOI: http://dx.doi.org/10.32385/rpmgf.v35i1.11932

23. DeLamater J, Koepsel E. Relationships and sexual expression in later life: a biopsychosocial perspective. Sex Relatsh Ther. 2015;30(1): 37-59. DOI: https://doi.org/10.1080/14681994.2014.939506

24. Silva LA, Scorsolini-Comin F, Santos MA. Casamentos de longa duração: Recursos pessoais como estratégias de manutenção do laço conjugal. Psico-USF. 2017;22(2):323-35. DOI: https://doi.org/10.1590/1413-82712017220211

25. Silva EP, Nogueira IS, Labegalini CMG, Carreira L, Baldissera VDA. Perceptions of care among elderly couples. Rev Bras Geriatr Gerontol. 2019;22(1):180136. DOI: https://doi.org/10.1590/1981-22562019022.180136

26. Almeida T, Lourenço ML. Envelhecimento, amor e sexualidade: utopia ou realidade? Rev Bras Geriatr Gerontol. 2007;10(1):101-14. DOI: https://doi.org/10.1590/1809-9823.2007.10018

27. Rodrigues LR, Portilho P, Tieppo A, Chambo Filho A. Analysis of the sexual behavior of elderly women treated at a gynecological outpatient clinic. Rev Bras Geriatr Gerontol. 2018;21(6):724-30. DOI: http://dx.doi.org/10.1590/1981-22562018021.180090

28. Vieira KFL, Coutinho MPL, Saraiva ERA. A Sexualidade Na Velhice: Representações Sociais De Idosos Frequentadores de Um Grupo de Convivência. Psicol Ciênc Prof. 2016;36(1):196-209. DOI: https://doi.org/10.1590/1982-3703002392013

29. Jackson SE, Firth J, Veronese N, Stubbs B, Koyanagi A, Yang L, et al. Decline in sexuality and wellbeing in older adults: A population-based study. J Affect Disord. 2019;245:912-7. DOl: https://doi.org/10.1016/j.jad.2018.11.091

30. Araújo BJ, Sales CO, Cruz LFS, Moraes Filho IM, Santos OP. Qualidade de vida e sexualidade na população da terceira idade de um centro de convivência. Rev Cient Sena Aires [Internet]. 2017 [cited 2020 Oct 28];6(2):85-94. Available from: http://revistafacesa.senaaires.com. br/index.php/revisa/article/view/282/183

Financial Support

This research was carried out with the support of the Coordination of Higher Education Personnel - Brazil (CAPES) - Financing Code 001 